\title{
Tarla Sarmașıkları Convolvulus lineatus, C. arvensis ve C. galaticus Türlerinin Karșılaștırmalı Morfolojik ve Anatomik Yapıları
}

\author{
*Ebru ATAȘLAR \\ *Eskișehir Osmangazi Üniversitesi, Fen Edebiyat Fakültesi, Biyoloji Bölümü, Eskișehir, Türkiye \\ *Corresponding author e-mail (Sorumlu yazar e-posta): eataslar@ogu.edu.tr
}

\section{Öz}

Bu çalıșmada, üç tarla sarmașığı türünün Convolvulus lineatus L., Convolvulus arvensis L. ve Convolvulus galaticus Rost. ex Choisy morfolojik ve anatomik yapısı incelenmiștir. Morfolojik incelemelerde gövde ve yaprak özellikleri, çiçek ve çiçek durumlarına ait özellikler belirtilmiștir. Ayrıca incelenen türlerin çiçeklenme zamanları, yayılıș gösterdikleri habitatların özellikleri ve yükseklik bilgileri verilmiștir. Anatomik incelemelerde kök, gövde ve yaprak özellikleri belirlenmiștir. Ayrıca, stoma ve yaprakların epidermal hücreleri incelenmiștir. Sonuç olarak, üç Convolvulus L. türünün gerek morfolojik gerekse anatomik özellikleri bakımından benzerlikleri ve farklııkları tartıșılmıștır.

Anahtar Kelimeler: Convolvulaceae, Convolvulus L., tarla sarmașığı, morfoloji, anatomi

\section{Comparative Morphological and Anatomical Structure of Convolvulus lineatus, C. arvensis and C. galaticus}

\section{Abstract}

In this study, morphological and anatomical structure of Convolvulus lineatus L., Convolvulus arvensis L. and Convolvulus galaticus Rost. ex Choisy were investigated. Morphological investigations of the stem and leaf characteristics, flower and flower characteristics were specified. In addition, flowering times of the species, characteristics of the habitat and the altitude information were given. In anatomical examinations, root, stem and leaf characteristics were determined. Also, stomata and epidermal cell of leaves were examined. In conclusion, the similarities and differences of three Convolvulus L. species in terms of both morphological and anatomical features were discussed.

Keywords: Convolvulaceae, Convolvulus L., field bindweed, morphology, anatomy

\section{Giriș}

C onvolvulaceae Juss. familyası dünyada 67 cins ve yaklașık 1500 tür ile temsil edilmektedir (http://www.theplantlist. org/). Familya üyeleri tropik, subtropik, kuzey ve güney yarıkürenin ılıman bölgelerinde yayılıș göstermekte olup ağaç, çalı ve otsu formları bulunmaktadır (Seçmen ve ark., 2008). Familyaya ait Türkiye'de 6 cins ve 61 tür bulunmaktadır (Güner ve ark., 2012).

Convolvulus L. cinsi monografı Wood ve ark. (2015) tarafından yayınlanmıștır. Dünyadaki tarla sarmașıklarının ayrıntılı bir envanterinin olușturulduğu bu çalıșmada, 190 tür tanımlanmıș ve çizimleri gerçekleștirilmiștir.
Ayrıntılı tür teșhis anahtarlarının da verildiği çalıșmada ayrıca dört tane de yeni tür tanımlanmıștır.

Convolvulus cinsi 35 türle familyanın ülkemizdeki en büyük temsilcisidir ve 39 takson ile temsil edilmektedir (Davis, 1978; Güner ve ark., 2012). Cins ile ilgili Türkiye'de yapılan çalıșmalara bakıldığında oldukça sınırlı sayıda makaleye rastlanılmaktadır. Bu konudaki en kapsamlı sistematik çalıșma Aykurt ve Sümbül (2014) tarafından gerçekleștirilen "Türkiye Convolvulus (Convolvulaceae) cinsinin taksonomik revizyonu" bașlıklı çalıșmadır. $\mathrm{Bu}$ çalıșmada cinsin türlerine, alttür ve 
varyetelerine ait teșhis anahtarları, taksonların sinonimleri, ayrıntılı morfolojik betimleri, çizimleri ve yayılıș haritaları sunulmuștur. Aynı araștırıcıların "C. oleifolius Desr. (Convolvulaceae)'un Türkiye'deki varyeteleri ve korolojisi" bașlıklı makalesinde ise türün iki varyetesine ait betimler, yayılıș alanları ve polen morfolojileri karșılaștırmalı olarak sunulmuștur (Aykurt ve Sümbül, 2010).

Cinsin polen morfolojisi ile ilgili bir bașka çalıșma ise Tekin ve Yılmaz (2016) tarafından gerçekleștirilmiș olup 6 tarla sarmașığı türünün polen yapıları ıșık ve elektron mikroskobu ile çalıșılarak morfolojileri ayrıntılı olarak verilmiștir. $\mathrm{Bu}$ çalıșmada $C$. lineatus ve $C$. galaticus türlerinin polen morfolojileri görülebilir.

C. arvensis türünün yerel kullanım biçimi ile kök, gövde ve yapraklarının protein, sodyum ve potasyum içeriğinin belirlendiği bir araștırma Yücel ve ark., 2011 tarafından "Kisecik Kasabası (Karaman) ve çevresinde bulunan bazı yabani bitkilerin kullanım biçimleri ve besin öğesi içeriklerinin belirlenmesi” bașlıklı makalede verilmiștir. Ayrıca C. arvensis'in de içinde yer aldığı bazı etnobotanik çalıșmalar bulunmaktadır. Uysal ve ark., 2010 tarafından “Kapıdağ yarımadası'nın (Türkiye) etnobotanik özellikleri” ve Saraç ve ark., 2013 tarafından "Rize ilinin etnobotanik özellikleri" bașlıklı çalıșmalarda olduğu gibi. C. pluricaulis Choisy'nin geleneksel kullanımı ve tıbbi önemi ile ilgili benzer bir çalıșma da Bhowmik ve ark. (2012) tarafından gerçekleștirilmiștir.

C. galaticus türü ile ilgili bir çalıșmada, Türker ve Yıldırım (2018) tarafından antioksidan aktivite ve fenolik içerik belirlenmiștir. Bu çalıșmada in-vitro olarak yetiștirilen bitkilerin fenolik içeriği ve antioksidan aktivitesi ile tarlada yetiștirilenlerinki karșılaștırılmıș ve ayrıntılı sonuçlar verilmiștir.

Convolvulaceaefamilyasınıntemelanatomik özellikleri ve türler arasında bazı önemli farklılıklar Metcalfe ve Chalk (1950) tarafından ayrıntılı olarak verilmiștir. Ayrıca Carlquist ve Hanson (1991) tarafından gerçekleștirilmiș bir bașka önemli anatomik çalıșma da familyanın gövde ve odun anatomisi çalıșılmıștır. Bu çalıșmada araștırıcılar 16 cins ve 35 türe ait olan toplam 44 örnek üzerinde çalıșmıșlar ve özellikle odunsu formları kapsayan türlerin anatomik yapılarını ortaya koymușlardır. Çalıșmada yer alan üç Convolvulus türü de çalı formunda olan C. cneorum L., C. floridus L. ve C. scoparius L. f. türleridir.

Ayrıca aynı familyada yer alan ve Convolvulus cinsine yakın olan Ipomoea cinsi ile ilgili anatomik çalıșmalar da bulunmaktadır. Ipomoea hederifolia Linn.'nın morfolojik ve anatomik özellikleri Lowel ve Lucansky (1986) tarafından çalıșılmıș olup bu çalıșmada özellikle floem ve sekonder ksilemin ayrıntılı yapıları üzerinde durulmuștur. Aynı türün odun anatomisi ile ilgili bir çalıșma ise Rajput ve ark. (2013) tarafından gerçekleștirilmiș olup 1986'daki çalıșmanın devamı niteliğini tașımaktadır. Burada ise özellikle sekonder floemin varlığı araștırılmıștır.

\section{Materyal ve Yöntem}

Convolvulus cinsine ait üç tür Eskișehir Osmangazi Üniversitesi Kampüsü'nden toplanmıș, standart herbaryum tekniklerine göre herbaryum örneği haline getirilmiș (Bridson ve Forman, 1999) ve Convolvulus lineatus L. ("top yayılgan"), C. arvensis L. ("tarla sarmașığı") ve C. galaticus Rost. ex Choisy ("boz sarmașık") türleri olarak tayin edilmiștir (Davis, 1978; Güner ve ark., 2012) (Șekil 1 A-C).

Ayrıca anatomik incelemeler için örnekler \% 70’lik alkolde saklanılmıștır. Her tür için kök, gövde, yaprak enine kesitleri ile yaprak yüzeysel kesitleri alınarak, gliserin-jelatin ile kalıcı preperatlar haline getirilmiștir (Vardar, 1987). İncelemeler ıșık mikroskobu ile yapılmıș olup fotoğrafların çekimi için Olympus CX41 dijital kamera kullanılmıștır.

Anatomik terminoloji için Metcalfe (1946), Metcalfe ve Chalk (1950), Esau (1977), Stearn (1992) ve Beentje (2010)'den yararlanılmıștır.

\section{Bulgular}

Convolvulus lineatus L. - Syst. Nat., ed. 10. 2: 923.1759 (Șekil 1A)

\section{Morfolojik yapı:}

Tabanda odunsu yapılı, basık ipeksi tüylü, yatık veya dik durușlu, 3-30 cm boylanan çok yıllık bitkiler; çoğu zaman kökler sürünücü. 


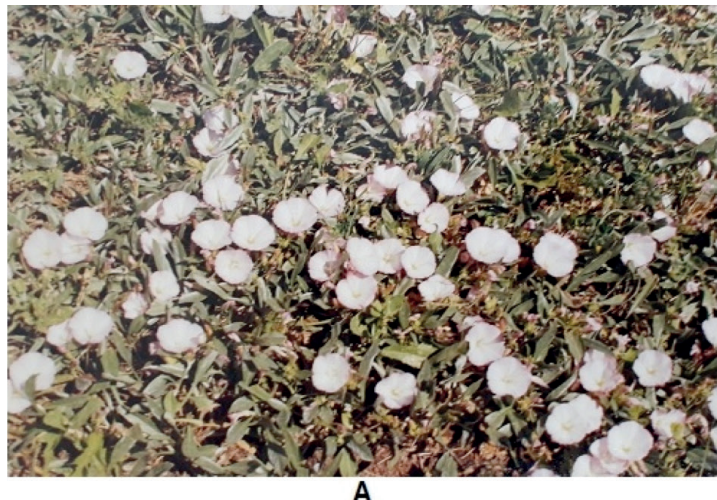

A
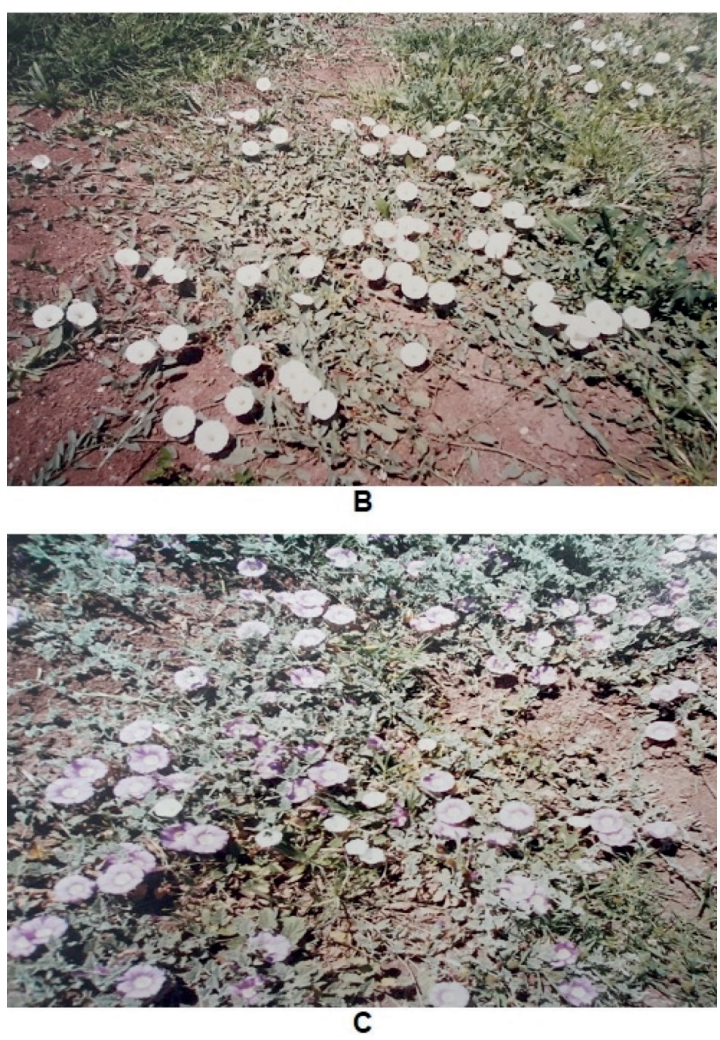

Șekil 1. Türlerin habitusları. A: Convolvulus lineatus L., B: Convolvulus arvensis L., C: Convolvulus galaticus Rost. ex Choisy

Figure 1. Habitus. A: Convolvulus lineatus, $B$ : Convolvulus arvensis, C: Convolvulus galaticus

Yapraklar șeritsi-eliptik, eliptik, șeritsi-ters mızraksıdan genișçe ters mızraksıya değișen biçimlerde, uçta küt veya sivri. Çiçekler yaprak koltuklarında ve uçta, tek veya kimoz çiçek durumlarında, 2-7 çiçekli. Sepaller parlak basık ipeksi tüylü, ovat veya köșeleri yuvarlakça bir dikdörtgen șeklinde, sivri veya uzun sivri uçlu. Korolla açık pembe veya beyaz, $15-25 \mathrm{~mm}$ boyunda.

Çiçeklenme dönemi: Nisan-Temmuz
Habitat: Artemisia stepleri, Quercus altları, kayalık yamaçlar, yol kenarları, kuru alanlar, nadasa bırakılmıș tarlalar

Yetișme yüksekliği: 800-2100 m’ler arası

\section{Anatomik Yapı:}

Kök yapısının iki/çok yıllık özellik gösterdiği ve sekonder kalınlașmanın olduğu görülmüștür. En dișta birkaç sıralı mantar tabakasına rastlanılmaktadır. Mantar tabakasının altında yer alan primer korteks, parankimatik hücrelerden olușmaktadır ve aralarında oldukça irileșmiș içleri turuncu-kahverengi olan salgı hücreleri yer almaktadır. Sekonder korteksi olușturan floem hücreleri fazla iri olmayan, düzgün sıralı parankimatik hücrelerden ve dar öz kollarından meydana gelmektedir. Kambiyum 1-2 sıralı oldukça küçük yassılașmıș hücrelerden olușmaktadır. Sekonder ksilem hücreleri ise daha çok sklerankimatik hücrelerden meydana gelmiș olup trakeler küçük ve çok sık değildir. Öz kolları belirgin olup, ince șeritler halinde dar olarak bulunmaktadır. Sekonder ksilemden sonra öze doğru birkaç sıralı primer ksilem hücreleri bulunmaktadır. Öz parankimatik olup, yine yer yer salgı hücrelerine rastlanılmaktadır (Șekil 2A).

Gövde tek yıllıktır, sekonder kalınlașmaya rastlanılmamaktadır. En dıșta kalınlașmıș kütikula tabakası yer almaktadır. Kütikulanın altında, hücrelerinin yan çeperleri kalınlașmıș epidermis tabakası görülür. Epidermis hücrelerinin içlerinin salgı maddesi ile dolu olduğu görülmektedir. Korteksin, özellikle epidermisin altında yer alan, 3-4 sıra hücresi oldukça küçük parankimatik hücrelerden olușmaktadır ve bu hücrelerin de salgı maddesi ile dolu olduğu görülmektedir. Genel olarak korteks neredeyse 1/3'lük bir alan kaplamakta olup irili ufaklı parankimatik hücrelerden meydana gelmekte ve yer yer yırtılmaların olduğu boșluklara rastlanılmaktadır. Periskl gruplar halindeki sklerankimatik hücrelerden meydana gelmiștir, çeper kalınlașması fazla olmadığı için küçük halkalar șeklinde göze çarpmaktadır ve floemi çepeçevre sarmamaktadır. Floem hücreleri oldukça dar yer tutmakta olup, sklerenkima hücreleri ve kambiyum ararında sıkıșmıș, 5-6 sıralı yuvarlak/ köșeli hücrelerdir. Ksilem ıșınsal yönde dizilmiș küçük trakelerden ve etrafında çok küçük 


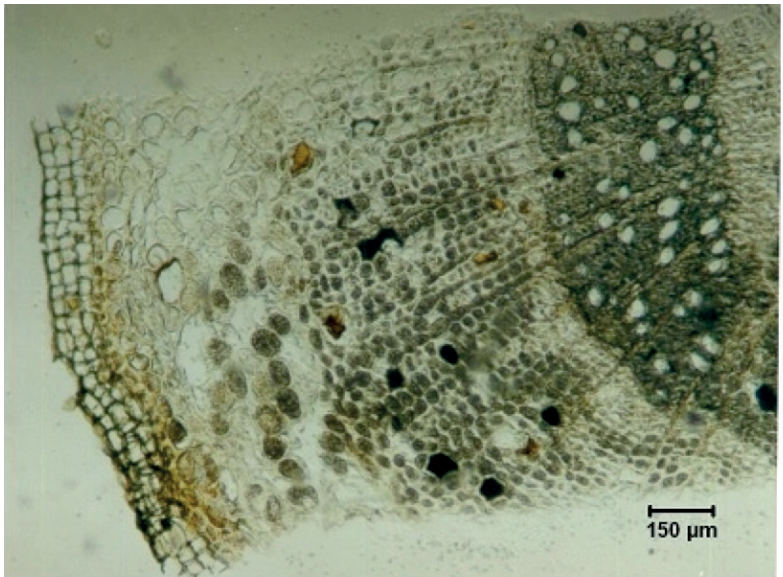

A

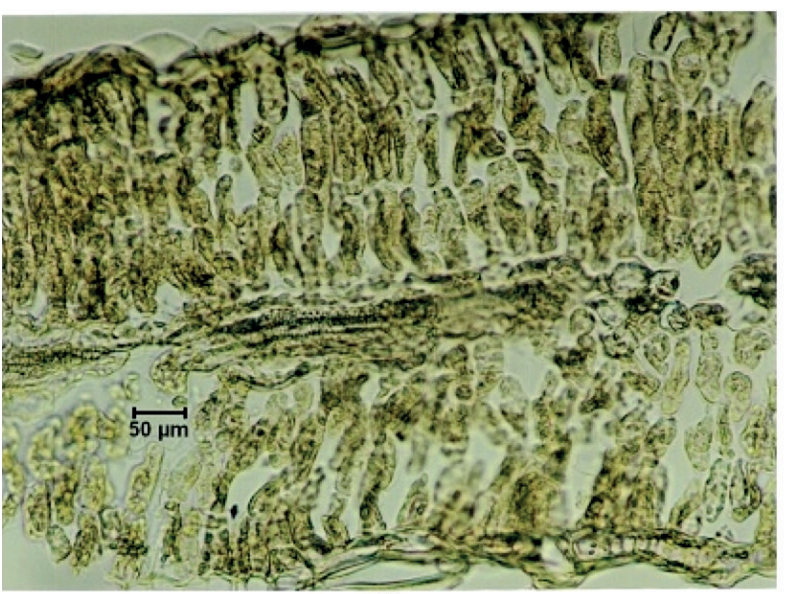

C

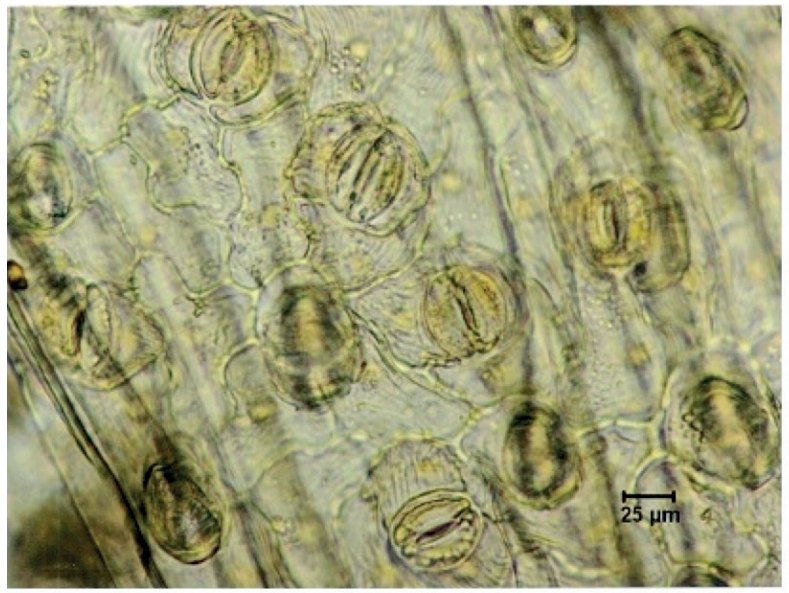

E

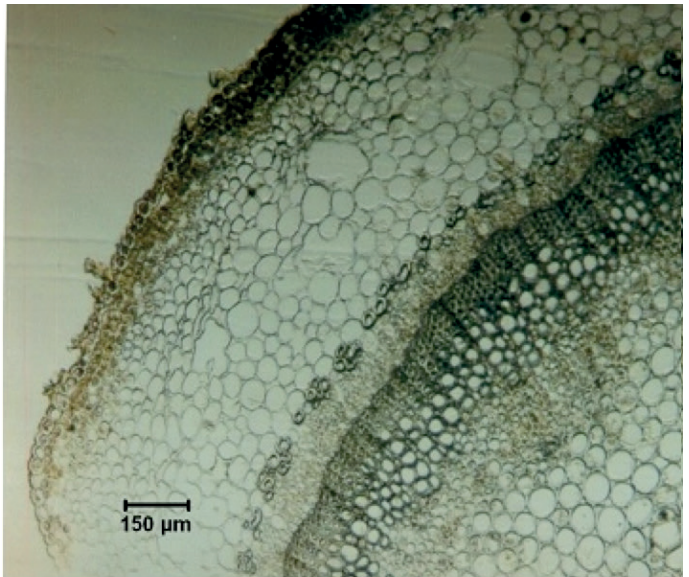

B

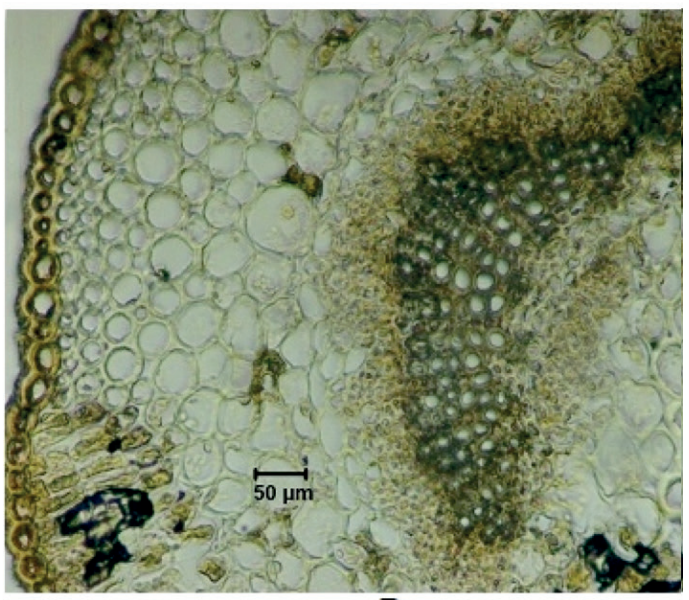

D

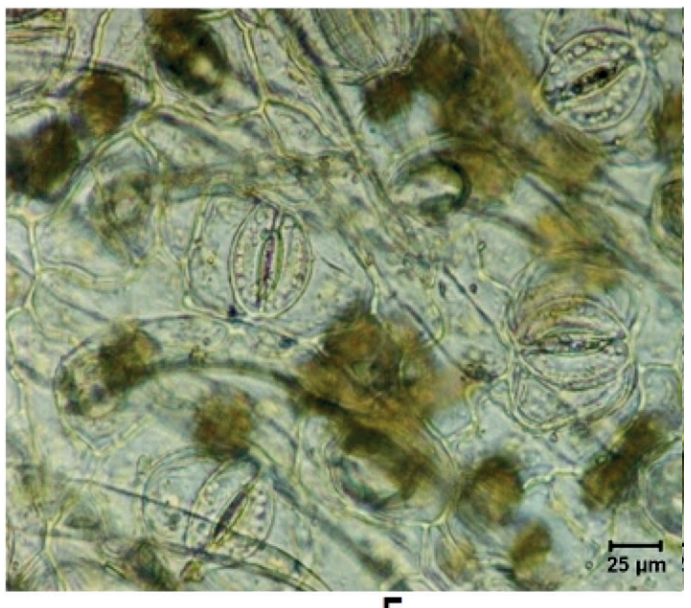

$\mathbf{F}$

Șekil 2. C. lineatus anatomik yapısı. A: Kök anatomisi, B: Gövde anatomisi, C: Yaprak mesofil yapıSı, D: Yaprak orta damar yapısı, E: Yaprak üst epidermisi, F: Yaprak alt epidermisi

Figure 2. Anatomical structure of C. leneatus. A: Root anatomy, B: Stem anatomy, C: Leaf mesophyll, D: Midrib, E: Upper epidermis, F: Lower epidermis

trakeidlerden meydana gelmektedir. Öze doğru ksilem hücrelerinin çapları artmaktadır. Ksilem hücrelerinden sonra öze doğru tekrar floem hücrelerinin varlığı iletim demetinin bikolateral demet olduğunu göstermektedir. Öz bölgesi tamamen parankimatik olup neredeyse 1/3'lük diğer alanı kaplamakta ve yer yer salgı hücrelerine rastlanılmaktadır (Șekil 2B). 
Yaprak enine kesitinde en dıșta ince bir kütikulanın ardından iri epidermis hücreleri görülmektedir. Șekilleri, hem üst hem de alt epidermiste az çok yuvarlak/dikdörtgenimsi olan bu hücreler, çok sık dizilmiștir kalınlașma göstermemektedir. Stoma hücreleri epidermis ile aynı hizada bulunmaktadır (mesomorf stoma). Stoma altı boșluk oldukça dardir. Dorsiventral (bifasial) olan yaprağın mesofil tabakasında 3 sıra halinde bol kloroplastlı palizat parankimasına ve 3-4 sıralı sünger parankimasına rastlanır (Șekil 2C).

Orta damar alt epidermise doğru belirgin bir çıkıntı yapmaktadır. Buradaki kütikula mesofildekine göre daha kalındır. Epidermis hücrelerinin çeperlerindeki kalınlașma da net olarak ayırt edilebilmektedir. Parankimatik hücreler 8-9 sıra olușturmakta olup, çapları epidermisden iletim demetine doğru artmaktadır. Iletim demeti bikolateraldir, yani ksilem iki floem arasında yer almaktadır. Ksilem elemanları floem elemanlarına göre daha fazla yer kaplamaktadır. Demet kını yoktur. Üst epidermis ile iletim demeti arasını ise yine parankimtik hücreler doldurmakta olup, kalınlığı 3-4 sıradır (Șekil 2D).

Hem üst hem de alt epidermis stoma tașımakta olup, yaprak amfistomatiktir. Stomalar amarillis tiptedir. Etrafı 2 ile 4 arasında değișen sayıda stoma komșu hücresi tarafından çevrilmektedir. Hücre çeperleri fazla derin olmayan, dalgalı bir yapı göstermektedir. Üst epidermiste çok belirgin olmayan kutikula süsleri vardır. Yaprağın hem alt hem de üst yüzeyi basit tek hücreli tüyler ile kaplıdır (Șekil 2E-F).

Convolvulus arvensis L. - Sp. PI., 1: 153. 1753 (Șekil 1B)

\section{Morfolojik yapı:}

Rizomları dallanmıș, sürünücü veya sarılıcı çok yıllık bitkiler. Toprak üstü gövdeleri $3 \mathrm{~m}$ uzunluğa kadar, tüysüz veya ince-yumușak tüylü. Yapraklar ok șeklinde veya alt lopları orta eksenden uzaklașmıș ok șeklinde, $5 \times 3$ $\mathrm{cm}$, tüysüz veya çok seyrek kısa-yumușak tüylü, sivri veya küt uçlu,. Çiçekler genellikle tek, yaprak koltuklarında, bazen 1 çift, nadiren kimoz çiçek durumlarında ve 3 - çiçekli. Sepaller yumurtamsıdan dikdörtgensiye değișen biçimlerde, $4 \times 2.5$ mm, uçta küçük sivri çıkıntılı. Korolla beyaz veya pembe, 15-25 $\mathrm{mm}$ boyunda.

Çiçeklenme dönemi: Nisan-Eylül

Habitat: Kumlu step alanlar, nadasa bırakılmıș tarlalar, otlak-meralar, yamaç eteklerinde biriken taș toprak yığınları, rüzgarın yığdığı kum tepeleri, yol kenarları

Yetișme yüksekliği: 1-3000 m

\section{Anatomik yapı:}

Kök yapısının iki/çok yıllık özellik gösterdiği ve sekonder kalınlașmanın olduğu görülmüștür. En dıșta birkaç sıralı mantar tabakasına rastlanılmaktadır. Primer korteks, parankimatik hücrelerden olușmaktadır. Parankima hücreleri içinde druz kristalleri görülmektedir. Primer kortekste yer yer oldukça küçük gruplar olușturmuș halde sklerankima hücrelerine rastlanılmaktadır. Sekonder korteksi olușturan floem hücreleri sekonder ksileme göre oldukça az yer kaplamakta olup, yer yer druz kristalleri bulunmaktadır ve öz ıșınları belirgindir. Kambiyum 1-2 sıralı oldukça küçük yassılașmıș hücrelerden olușmaktadır. Merkezi silindirin oldukça büyük bir kısmını sekonder ksilem hücreleri kaplamaktadır. Burada trakeler çok iridir ve öz ıșınlarının, öz bölgesine kadar uzanıșı net olarak gözlenebilmektedir. Öz parankimatik olup, parankima hücrelerin içi depo maddesi ile doludur. Ayrıca druz kristalleri de gözlenmektedir (Șekil 3A).

Gövde tek yıllıktır, sekonder kalınlașmaya rastlanılmamaktadır. En dıșta kütikula tabakası yer almaktadır. Kütikulanın altında tek sıralı bir epidermis tabakası görülür. Epidermis hücreleri irice oval/dikdörtgen hücrelerden meydana gelmektedir. Hücrelerin içinde yer yer salgı maddesi görülmektedir. Korteks iki farklı hücre grubundan meydana gelmektedir. Epidermisin hemen altında yer alan 2-3 sıralı parankimatik hücrelerin içleri salgı maddesi ile doludur. Daha sonra ise 5-6 sıralı çeperleri kalınlașmaya bașlamıș kollenkimatik hücreler gözlenmektedir. Periskl tabakası 1-2 sıralı tam bir daire olușturmadan, yer yer kesintilere uğrayan sklerankimatik hücrelerden olușmaktadır. Floem hücreleri oldukça az yer tutmakta olup, 3-4 sıralı yuvarlak/köșeli hücrelerdir. Kambiyum 1-2 sıralı yassılașmıș șekilsiz hücrelerden meydana gelmektedir. Ksilem ıșınsal yönde dizilmiș tra- 


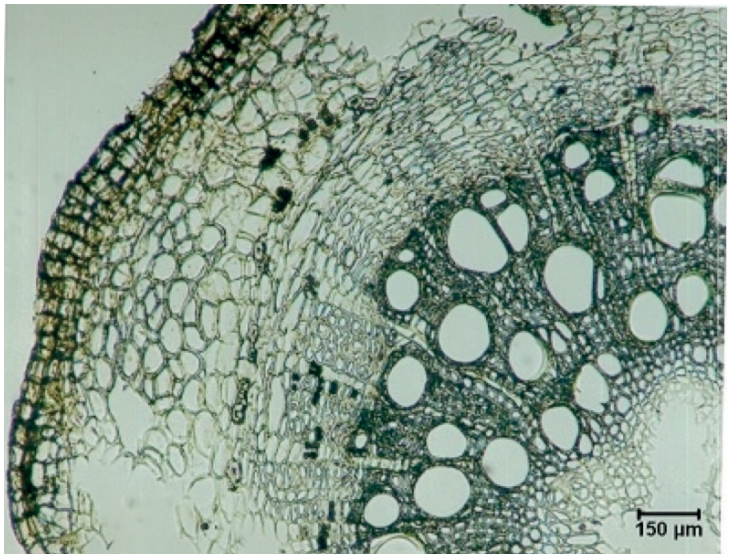

A

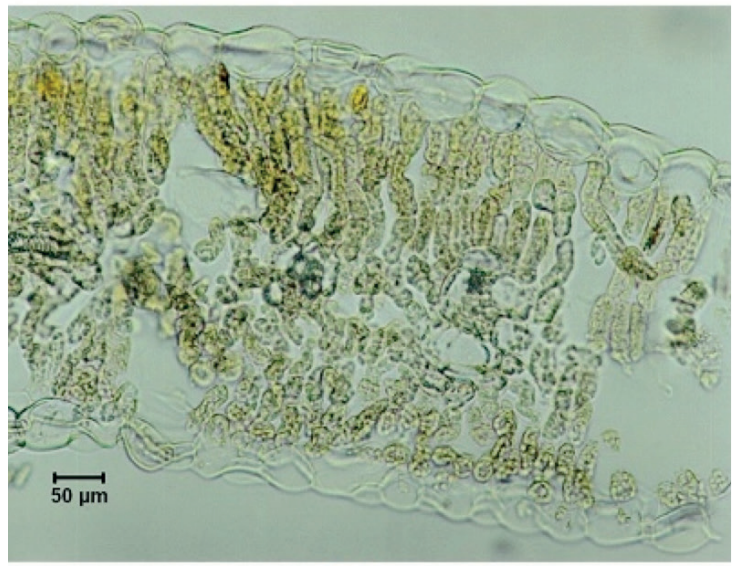

C

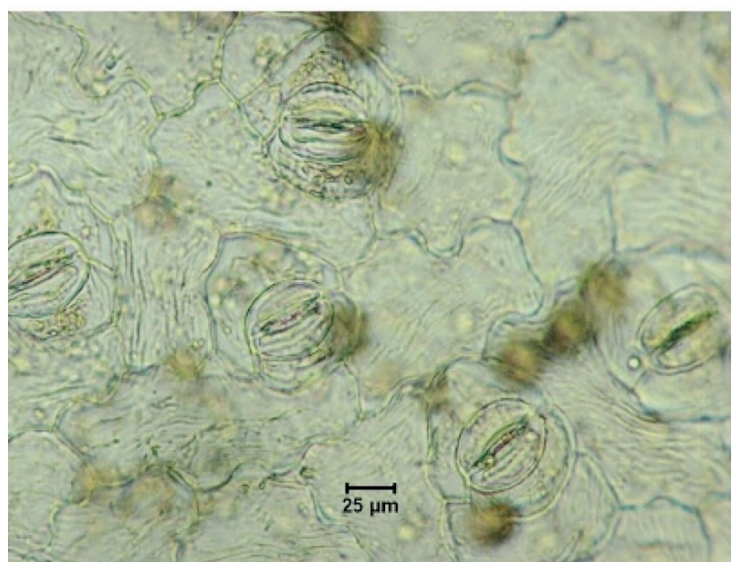

E

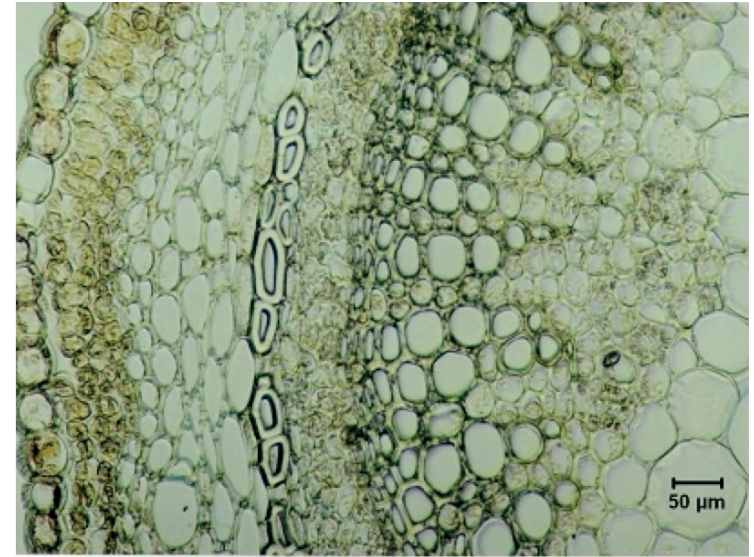

B

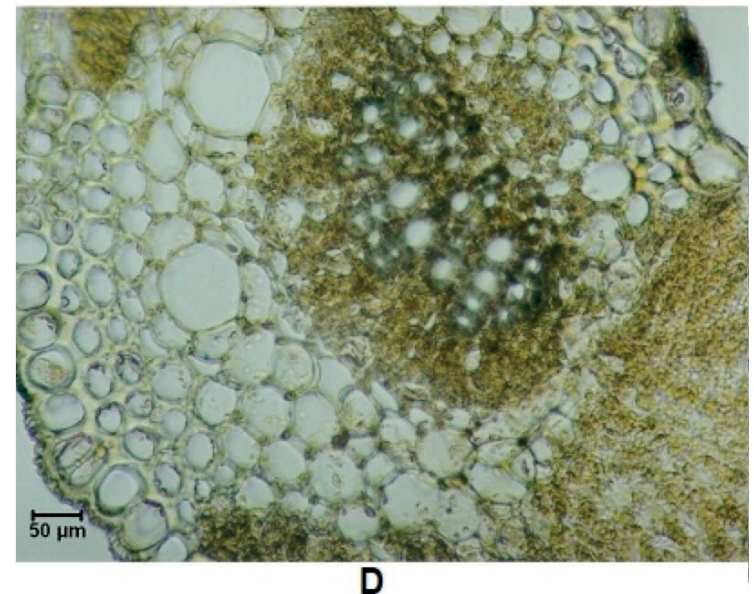

D

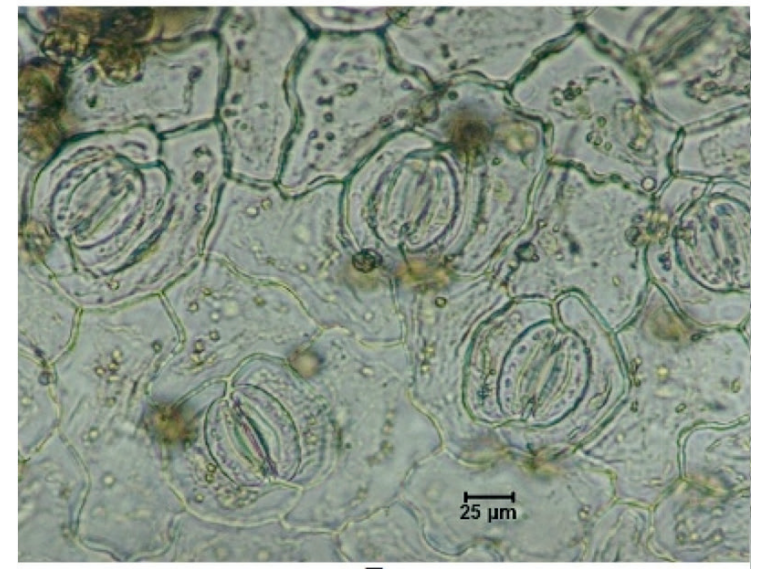

$\mathbf{F}$

Șekil 3. C. arvensis anatomik yapısı. A: Kök anatomisi, B: Gövde anatomisi, C: Yaprak mesofil yapısı, D: Yaprak orta damar yapısı, E: Yaprak üst epidermisi, F: Yaprak alt epidermisi

Figure 3. Anatomical structure of C. arvensis. A: Root anatomy, B: Stem anatomy, C: Leaf mesophyll, D: Midrib, E: Upper epidermis, F: Lower epidermis

kelerden ve etrafındaki oldukça küçük trakeidler meydana gelmektedir. Ksilemde yer yer trakelerin oldukça büyük hücrelerden meydana geldiği görülmektedir. Ksilemin hem iç hem de dıș tarafında floem hücrelerinin bulunması bikolateral demet varlığını göstermektedir. Öz büyük parankimatik hücrelerden meydana gelmiș olup, oldukça geniș bir yer kaplamaktadır. Burada yer yer druz kristallerine rastlanılmaktadır (Șekil 3B).

Yaprak enine kesitinde en dișta ince bir kütikulanın ardından iri epidermis hüreleri 
görülmektedir. Șekilleri, hem üst hem de alt epidermiste az çok oval/dikdörtgen olan bu hücrelerde çeper kalınlașması yoktur. Stoma hücreleri epidermis ile aynı hizada bulunmaktadır (mesomorf stoma). Dorsiventral (bifasial) olan yaprağın mesofil tabakasında 2-3 sıra halinde bol kloroplastlı palizat parankimasına ve 3-4 sıralı sünger parankimasına rastlanılmaktadır (Șekil 3C).

Orta damar çıkıntısı belirgindir ve alt epidermise doğrudur. İri parankimatik hücrelerin olușturduğu bu kısımda, 5-6 sıralı hücre tabakasına rastlanımaktadır. İletim demeti bikolateraldir, yani ksilem iki floem arasında yer almaktadır. Ksilem elemanları floem elemanlarına göre daha fazla yer kaplamaktadır. Demet kını yoktur. Üst epidermis tarafında ise yine parankimatik hücreler bulunmaktadır, ancak burada 2-3 sıra olușturmușlardır ve çapları dardır (Șekil 3D).

Hem üst hem de alt epidermis stoma tașımakta olup, yaprak amfistomatiktir. Stomalar amarillis tiptedir. Etrafı 2 ile 4 arasında değișen sayıda stoma komșu hücresi tarafından çevrilmektedir. Hücre çeperleri üst epidermis ile alt epidermiste farklılık göstermektedir. Üst epidermiste kutikula süsleri çok belirgindir ve hücre çeperleri fazla derin olmayan, dalgalı bir yapı göstermektedir. Ancak alt epidermiste kutikula süsü bulunmamakta ve hücre çeperleri düz olup dörtgen/beșgen șekillidir (Șekil 3E-F).

Convolvulus galaticus Rost. ex Choisy Prodr. [A. P. de Candolle] 9: 408.1845 (Șekil 1C).

\section{Morfolojik yapı:}

Rizomlu, toprak üzerinde yatık gelișen, parlak kadifemsi tüylü, sarılıcı veya sürünücü, çok yıllık otsu bitkiler, . Yapraklar saplı, genișçe yumurtamsı biçimli, uçta sivri veya küçük sivri çıkıntılıtabanda kalpsi, dalgalı dișlikenarlı. Çiçekler yaprak koltuklarında, tek veya kimoz çiçek durumlarında, 2-4 çiçekli. Sepaller yumurtamsı, uç kısmı tepecikli, yoğun kıtıksı tüylü. Korolla pembeden açık mora kadar değișen renklerde, 25-35 mm boyunda.

Çiçeklenme dönemi: Mayıs-Ağustos

Habitat: Çam ormanları, açık step alanlar, tașlık yamaçlar, çayırlar, ekili ve nadasa bırakılmıș tarlalar

Yetișme yüksekliği: 880-2000 m

\section{Anatomik yapı:}

Kök yapısının iki/çok yıllık özellik gösterdiği ve sekonder kalınlașmanın olduğu görülmüștür. En dıșta birkaç sıralı mantar tabakasına rastlanılmaktadır. Mantar tabakasının altında yer alan primer korteks, parankimatik hücrelerden olușmaktadır ve yer yer gruplar olușturmuș sklerankimatik hücrelere rastlanılmaktadır. Parankima hücreleri içinde druz kristalleri görülmektedir, bazı hücrelerin içerisinde 4-5 küçük druz kristali sayılabilmektedir. Sekonder korteksi olușturan floem hücreleri içerisinde de yer yer druz kristallerine rastlanılmaktadır. Kambiyum 1-2 sıralı oldukça küçük yassılașmıș hücrelerden olușmaktadır. Sekonder ksilemde trakelerin yoğunluğu oldukça azdır ve çapları dardır. Daha çok trakeidlerden ve sklerankimatik hücrelerden olușan bu bölgede öz ıșınları çok dar olarak bulunmakta ve nadiren yer yer göze çarpmaktadır. Sekonder ksilemden sonra, oldukça dar yer kaplayan primer ksilem hücreleri bulunmaktadır. Öz parankimatiktir (Șekil 4A).

Gövde tek yıllıktır, sekonder kalınlașmaya rastlanılmamaktadır. En dișta kütikula tabakası yer almaktadır. Kütikulanın altında tek sıralı epidermis tabakası görülür. Epidermis hücreleri yuvarlak/oval hücrelerden meydana gelmektedir. Basit tek hücreli örtü tüyler gövdeyi kaplamaktadır. Epidermisin altında yer alan 2-3 sıralı parankimatik hücrenin salgı maddesi ile dolu olduğu görülmektedir. Devamında ise 2-3 sıra olușturan çeperleri kalınlașmaya bașlamıș kollenkimatik hücreler bulunmaktadır ve burada da yer yer salgı hücrelerine rastlanılmaktadır. Periskl tabakası 1-2 sıralı sklerankimatik hücrelerden olușmaktadır ve merkezi silindiri tamamen sarmaktadır. Floemin 5-6 sıralı iri hücrelerden oluștuğu gözlenmektedir. Kambiyum 1-2 sıralı yassılașmıș șekilsiz hücrelerden meydana gelmektedir. Ksilemde trakeler iki farklı șekilde yer almaktadır: kambiyumun hemen altında 2-3'lü gruplar halinde çok iri trakeler ve öze doğru çapları daralan trake dizileri. Öze doğru çıkıntı yapan floem hücrelerinin varlığı bikolateral demet olduğunu göstermektedir. Öz tamamen parankimatik olup, gövde çapının yarısını hatta neredeyse 2/3'lük kısmını kaplamaktadır. Burada yer yer salgı hücrelerine rastlanılmaktadır (Șekil 4B). 


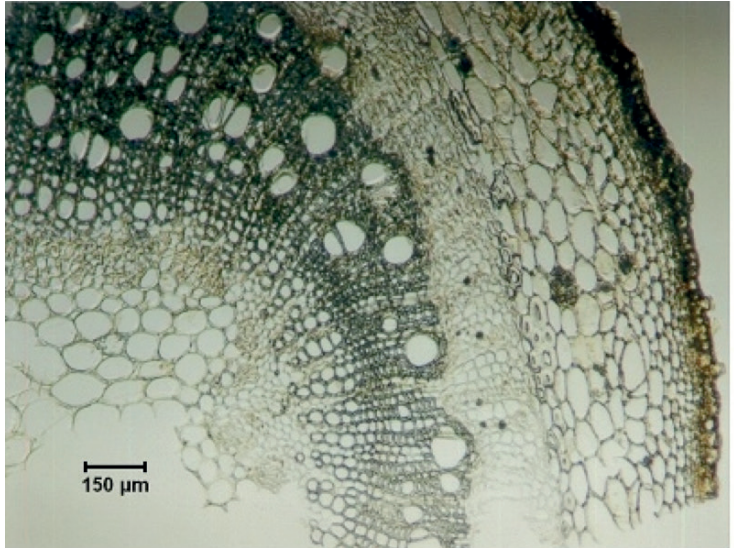

A

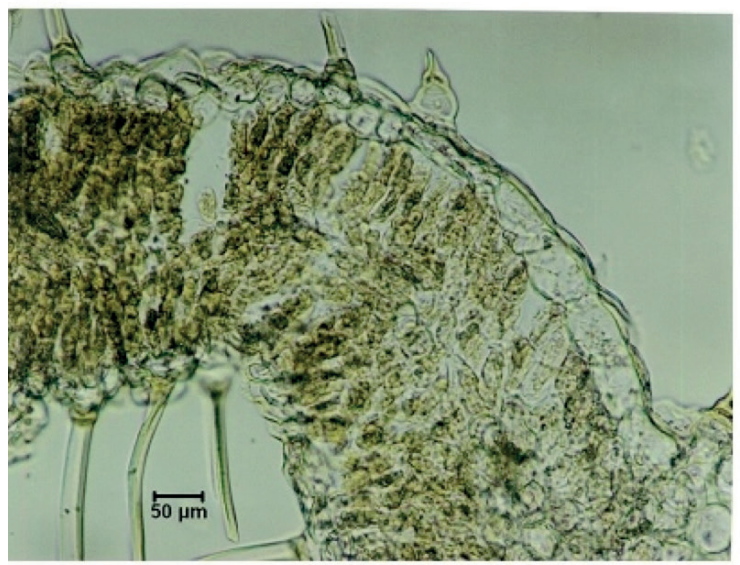

C

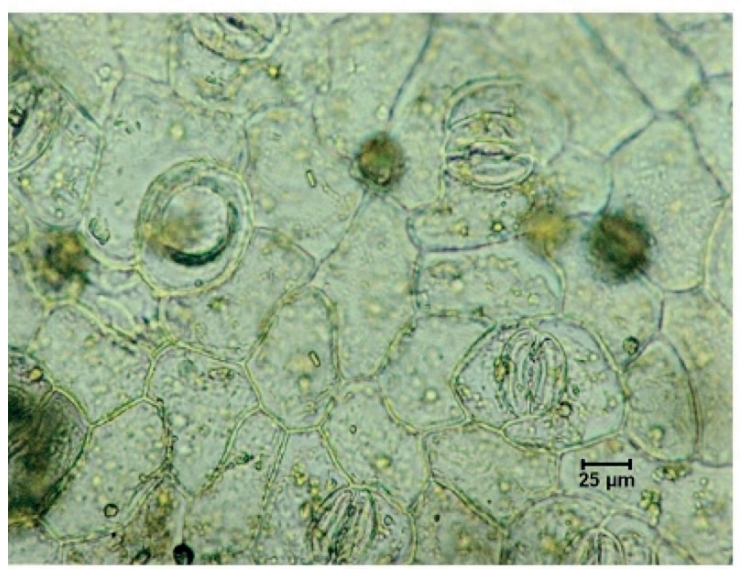

E

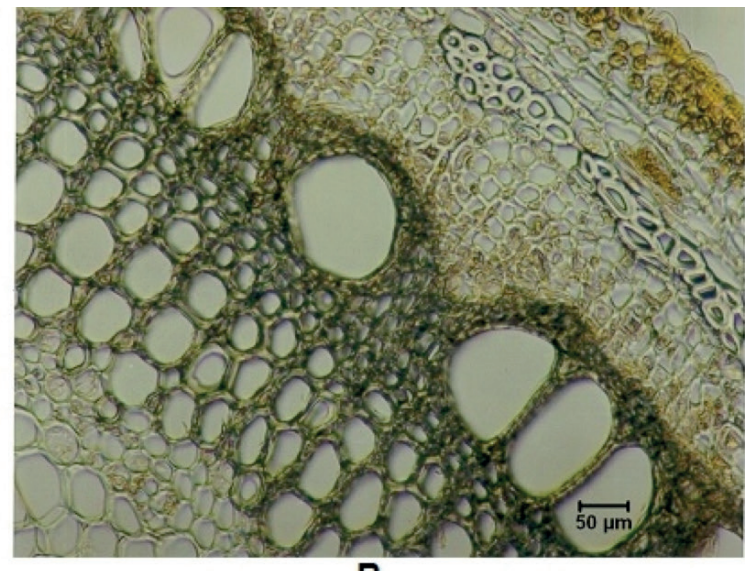

B

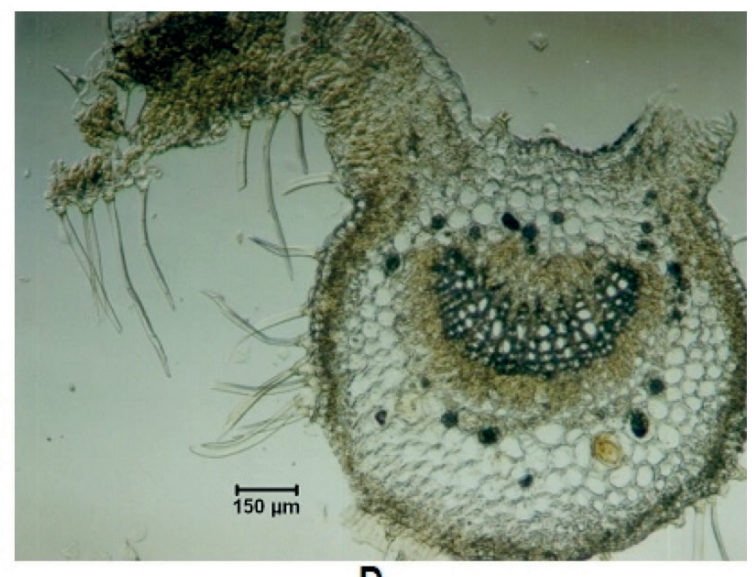

D

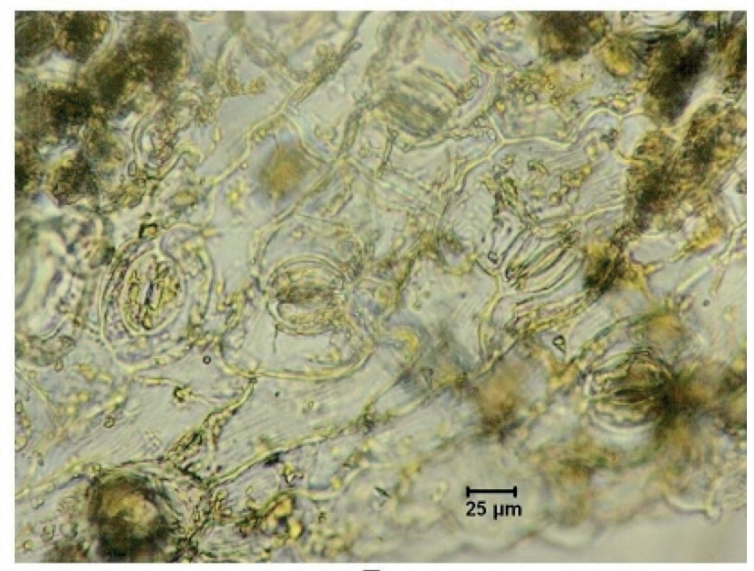

F

Șekil 4. C. galaticus anatomik yapısı. A: Kök anatomisi, B: Gövde anatomisi, C: Yaprak mesofil yapısı, D: Yaprak orta damar yapısı, E: Yaprak üst epidermisi, F: Yaprak alt epidermisi

Figure 4. Anatomical structure of C. galaticus. A: Root anatomy, B: Stem anatomy, C: Leaf mesophyll, D: Midrib, E: Upper epidermis, F: Lower epidermis

Yaprak enine kesitinde en dișta ince bir kütikulanın ardından iri epidermis hücreleri görülmektedir. Üst epidermiste oldukça iri olan hücrelerin șekilleri, az çok yuvarlak/dikdörtgen șekillidir ve çok sık dizilmișlerdir, yani çeper kalınlașması yoktur. Tüyler, alt epidermiste daha yoğundur ve gövdede yer alanlardan daha uzun olmakla birlikte yine tek hücreli basit örtü tüyleridir. Stoma hücreleri epidermis ile aynı hizada bulunmaktadır (mesomorf 
stoma). Yaprak mesofilinin isolateral (ekvifasiyal) olduğu görülmüștür. Yaprak, hem üst epidermisin altında hem de alt epidermisin üzerinde palizat parankimaları tașımaktadır. Her iki yöndeki kalınlığı 2-3 sıra kadardır. Sünger parankiması hücreleri ise 1-2 sıra halinde yuvarlak hücreler olarak bulunmaktadır (Șekil 4C).

Yaprak orta damarının alt epidermise doğru yaptığı çıkıntı çok iri olup neredeyse mesofilin 2-3 katı kadar kalınlıkta bir çap ile küresel bir görüntü sergilemektedir. Çapları dar parankimatik hücreler ile dolu olan bu kısımda yoğun druz kristalleri bulunmaktadır, ayrıca yer yer salgı hücrelerinin varlığı da göze çarpmaktadır. Illetim demeti bikollateraldir, yani ksilem iki floem arasında yer almaktadır. Demet kını yoktur. Ksilem elemanları ile floem elemanlarının kapladığı alan yaklașık olarak aynıdır. Üst epidermis ile iletim demeti arasını druz kristalli parankimtik hücreler doldurmakta olup, kalınlığı 5-6 sıradır (Șekil 4D).

Hem üst hem de alt epidermis stoma tașımakta olup, yaprak amfistomatiktir. Stomalar amarillis tiptedir. Etrafı 2 ile 4 arasında değișen sayıda stoma komșu hücresi tarafından çevrilmektedir. Hücre çeperleri daha çok hafif dalgalı özellik göstermektedir, kutikula süsleri gözlenmemiștir. Yoğun olan tüy örtüsü tek hücreli basit tüy yapısındadır (Șekil 4E-F).

\section{Tartıșma ve Sonuç}

Bu çalıșmada, üç tarla sarmașığı türünün Convolvulus lineatus L. ("top yayılgan"), Convolvulus arvensis L. ("tarla sarmașığı") ve Convolvulus galaticus Rost. ex Choisy ("boz sarmașık") morfolojik ve anatomik yapısı incelenmiștir.

Morfolojik incelemelerde gövde ve yaprak özellikleri,çiçekyapılarıvedurumları,çiçeklenme zamanları, bulundukları habitatın özellikleri ve yükseklik bilgileri verilmiștir. Morfolojik bulgular Türkiye Florası'nda sunulmuș betimlemeler ile uyum göstermektedir (Davis, 1978). Üç türe ait morfolojik karșılaștırma Tablo 1'de özetlenmiștir.

Anatomik incelemelerde her türün kök, gövde, yaprak enine kesitleri ile yaprak yüzeysel kesitleri alınarak anatomik yapıları belirlenmiștir.

Köklerin çok yıllık anatomik yapıya sahip oldukları ve sekonder kalınlașmanın net olarak ayırt edilebildiği görülmüștür. Kök korteksi parankimatikdir ancak C. lineatus'da salgı hücrelerinin, C. galaticus'da ise druz kristalli hücrelerin bulunușu ayırt edici özelliktir. Merkezi silindir de ise $C$. arvensis türünün ksilem hücreleri iri trakeler içermektedir.

Gövdelerin anatomik yapıları tek yıllık otsu forma uygun olarak sekonder kalınlașmanın

Tablo 1. Morfolojik özelliklerin karșılaștırılması

Table 1. Comparison of morphological features

\begin{tabular}{|c|c|c|c|}
\hline & C. lineatus & C. arvensis & C. galaticus \\
\hline Rizom & sürünücü, çok yıllık & sürünücü, çok yıllık & sürünücü, çok yıllık \\
\hline Gövde & $\begin{array}{l}\text { yatık gövdeli, yumușak } \\
\text { tüylü, tabanda odunsu, } \\
3-30 \mathrm{~cm} \text {.ye uzayabilen }\end{array}$ & $\begin{array}{l}\text { tüysüz, tabandan dallanmıș, } \\
3 \text { m.ye kadar uzayabilen }\end{array}$ & $\begin{array}{l}\text { yatık gövdeli, yoğun parlak } \\
\text { kıtıksı tüylü, } 50 \mathrm{~cm} \text {.ye kadar } \\
\text { uzayabilen }\end{array}$ \\
\hline Yaprak & $\begin{array}{l}\text { yaprak sapı yok, yaprak } \\
\text { ayası șeritsi-eliptikden } \\
\text { sivriye, tüylü }\end{array}$ & $\begin{array}{l}\text { yapraklar saplı, yaprak } \\
\text { ayası ok șeklinde, tüysüz }\end{array}$ & $\begin{array}{l}\text { yapraklar saplı, yaprak ayası } \\
\text { kalp șekilli yaklașık } 5 \text { loblu, } \\
\text { kıtıksı tüylü }\end{array}$ \\
\hline Çiçek durumu & kimoz, 2-7 çiçekli & tek veya bir çift & tek veya çift \\
\hline Sepal & $\begin{array}{l}\text { parlak renkli, ovat- } \\
\text { yumurtamsı }\end{array}$ & ovat-yumurtamsı & $\begin{array}{l}\text { genișce ovat-yumurtamsı, } \\
\text { yoğun kıtıksı tüylü }\end{array}$ \\
\hline Petal & açık pembe, $15-25 \mathrm{~mm}$. & $\begin{array}{l}\text { çoğunlukla beyaz, } 15-25 \\
\text { mm. }\end{array}$ & $\begin{array}{l}\text { mora çalan koyu pembe, } \\
25-35 \mathrm{~mm} \text {. }\end{array}$ \\
\hline Çiçeklenme zamanı & 4 - 7. aylar & 4 - 9. aylar & 5 - 8. aylar \\
\hline Habitat & $\begin{array}{l}\text { step, nadasa bırakılmıș } \\
\text { arazi, kaya yamaçları }\end{array}$ & $\begin{array}{l}\text { yol kenarları, tarla kenarları, } \\
\text { otlak ve meralar }\end{array}$ & $\begin{array}{l}\text { step, tașlık yamaçlar, ekili } \\
\text { veya nadasa bırakılmıș } \\
\text { tarlalar, kalkerli topraklar }\end{array}$ \\
\hline Yetișme yüksekliği & $800-2100 \mathrm{~m}$ & deniz seviyesinden 3000 m & $880-2000 \mathrm{~m}$ \\
\hline
\end{tabular}


olmadığı görülmektedir. Her üç türde de korteks parankimatikdir ancak C. lineatus ve C. arvensis'de periskl tabakasına doğru kollenkimatik kalınlașmıș hücre sıraları bulunurken, C. galaticus'un dar korteksinde bu duruma rastlanılmaz. Ayrıca yine $C$. lineatus ve C. arvensis'de periskl tabakasını olușturan sklerankimatik hücreler gruplar halinde bulunurken, C. galaticus'da merkezi silindiri kesintisiz olarak çevrelemektedir. Ayrıca C. galaticus ksileminde trakeler iki farklı șekilde yer almaktadır: kambiyumun hemen altında 2-3'lü gruplar halinde çok iri trakeler ve öze doğru çapları daralan trake dizileri. Bu durum da gövde için en ayırt edici özelliklerden birini olușturmaktadır. Öz bölgesi parankimatikdir; C. lineatus ve C. galaticus'da yer yer salgı hücrelerine, C. arvensis'de ise yer yer druz kristallerine rastlanmıștır.

Yaprak anatomisine bakıldığında türler arasındaki ayırt edici özelliğin mesofilde palizat ve sünger parankimasının yerleșim düzeninde olduğu görülmektedir. C. lineatus ve C. arvensis'de mesofil dorsiventral (bifasial) yapıda, C. galaticus'da ise isolateral (ekvifasiyal) yapıdadır. Palizat parankimasının mesofilin her iki yönünde de yer aldığı isolateral yapraklar, ksefofitik habitata uyumlu olan bitkilerde görülmektedir (Esau, 1977). Bu durum C. galaticus türünün seçtiği habitatlar ile uyum göstermektedir (Tablo 1). Ayrıca üç türün yaprak orta damarı karșılaștırıldığında da C. galaticus'da mesofilin 2-3 katı kadar kalınlıkta bir çap ile küresel yapı diğer türlerden farklılık göstermektedir.

Sonuç olarak, bu çalıșma tarla sarmașıkları olarak bilinen Convolvulus cinsine ait üç türün, C. lineatus, C. arvensis ve C. galaticus, morfolojik yapılarının karșılaștırılması ve ayrıntılı anatomik yapılarının belirlenerek türler arasındaki farklılıkların ortaya çıkarılması amacı ile yapılmıștır. Çalıșmanın Convolvulaceae familyası veya Convolvulus cinsi ile ilgili yapılmakta olan veya yapılacak çalıșmalara ön bilgi niteliği tașıması hedeflenilmiștir.

\section{Kaynaklar}

Aykurt, C. \& Sümbül, H. (2010). Varieties and chorology of Convolvulus oleifolius Desr. (Convolvulaceae) in Turkey. Biological Diversity and Conservation 3 (2), 155-162.
Aykurt, C. \& Sümbül, H. (2014). Taxonomic revision of the genus Convolvulus L. (Convolvulaceae) in Turkey. Biological Diversity and Conservation 7 (2), 10-37.

Beentje, H. (2010). Plant Glossary: An illustrated dictionary of plant terms. Kew: Kew Publishing, Royal Botanic Gardens.

Bhowmik, D., Kumar K.P.S., Paswan, S., Srivatava, S., Yadav, A.P.D. \& Dutta, A. (2012). Traditional Indian herbs Convolvulus pluricaulis and its medicinal importance. Journal of Pharmacognosy and Phytochemistry 1 (1), 4451.

Bridson, D. \& Forman, L. (1999). The Herbarium Handbook. Kew: Kew Publishing, Royal Botanic Gardens.

Carlquist, S. \& Hanson, M.A. (1991). Wood and stem anatomy of Convolvulaceae. Aliso 13 (1), 51-94.

Davis, P.H. (Ed) (1978). Flora of Turkey and East Aegean Islands Vol. 6. Edinburg: Edinburg University Press.

Esau, K. (1977). Anatomy of Seeds Plants, $2^{\text {th }}$ Edition. New York: John Wiley and Sons.

Güner, A., Aslan, S., Ekim, T., Vural, M. \& Babaç, M.T. (Edlr), (2012). Türkiye Bitkileri Listesi (Damarlı Bitkiler). İstanbul: Nezahat Gökyiğit Botanik Bahçesi ve Flora Araștırmaları Derneği Yayını.

Lowell, C. \& Lucansky, T.W. (1986). Vegetative anatomy and morphology of Ipomoea hederifolia (Convolvulaceae). Bulletin of the Torrey Botanical Club 113 (4): 382-397.

Metcalfe, C.R. (1946). The systematic anatomy of the vegetative organs of the Angiosperms. Biological Reviews 21 (4), 159-172.

Metcalfe, C.R. \& Chalk, L. (1950). Anatomy of the Dicotyledons Vol. 2. Oxford: Clarendon Press.

Rajput, K.S., Patil, V.S. \& Rao, K.S. (2013). Wood anatomy and the development of interxylary phloem of Ipomoea hederifolia Linn. (Convolvulaceae). Journal of Plant Growth Regulation 32, 654-662.

Saraç, D.U., Özkan, Z.C. \& Akbulut, S. (2013). Ethnobotanic features of Rize/Turkey province. Biological Diversity and Conservation 6 (3), 5766.

Seçmen, Ö., Gemici, Y., Görk, G., Bekât, L. \& Leblebici, E. (2008). Tohumlu Bitkiler Sistematiği. İzmir: Ege Üniversitesi Basımevi, Bornova.

Stearn, W.T. (1992). Botanical Latin: History, grammar, syntax, terminology and vocabulary, $4^{\text {th }}$ Edition. England: David and Charles Publishers.

Tekin, M. \& Yılmaz, G. (2016). Palynological studies of the genus Convolvulus L. (Convolvulaceae) from Turkey. Botanical Sciences 94 (3): 543549.

Türker, A.U. \& Yıldırım, A.B. (2018). Clonal propagation, antioxidant activity and phenolic profiles of Convolvulus galaticus Rostan ex Choisy. Romanian Biotechnological Letters 23 (3), 13625-13636. 
Uysal, İ., Onar, S., Karabacak, E. \& Çelik, S. (2010). Ethnobotanical aspects of Kapıdağ Peninsula (Turkey). Biological Diversity and Conservation 3 (3), 15-22.

Vardar, Y. (1987). Botanikte Preparasyon Tekniği. İzmir: Ege Üniversitesi Basımevi, Bornova.

Wood, J.R.I., Williams, B.R.M., Mitchell, T.C., Carine, M.A., Haris, D.J. \& Scotland, R.W. (2015). A foundation monograph of Convolvulus L. (Convolvulaceae). PhytoKeys 51: 1-282.
Yücel, E., Tapırdamaz, A., Yücel-Șengün, İ., Yılmaz, G. \& Ak, A. (2011). Determining the usage ways and nutrient contents of some wild plants around Kisecik Town (Karaman/Turkey). Biological Diversity and Conservation 4 (3), 71-82.

[Online] http://www.theplantlist.org/ (Erișim tarihi: 2018). 